\title{
THE SYNCHRONIC DYNAMICS OF WORDS ENDING IN -ita/-ost'
}

\author{
MÁRIA ŠIMKOVÁ \\ Slovak National Corpus, L. Štúr Institute of Linguistics, Slovak Academy of Sciences, \\ Slovakia
}

ŠIMKOVÁ, Mária: The synchronic dynamics of words ending in -ita/-ost'. Journal of Linguistics, 2019, Vol. 70, No 2, pp. 170 - 179.

\begin{abstract}
This paper focuses on the potential of using corpora to study manifestations of the synchronic dynamics of language and on the analysis of how words with the suffixes -ita/-ost' function in contemporary texts. The analysis is based on data from the Slovak National Corpus: the corpus of older texts (texts from 1955 to 1989), the primary corpus (texts from 1955 to 2017, especially since 2000), and the corpus of online texts (until 2017). A comparison of the frequency and collocations of the analyzed words shows the dynamics of these microsystems in the language of the previous and the current period.
\end{abstract}

Keywords: synchrony of the language, lexical analysis, dynamics of abstract terms, frequency, Slovak National Corpus

\section{SOURCES OF MATERIAL AND POSSIBILITIES OF RESEARCH OF SYNCHRONIC DYNAMICS OF LANGUAGE}

After a theoretical distinction between language synchrony and diachrony was established and as soon as the synchronic dynamics of language were accepted as relevant and clarified from a terminological perspective (e.g. [1], [2], [3]), new possibilities opened up in linguistic research, enabling the analysis of dynamic phenomena, processes, and trends in virtually all linguistic areas of contemporary language. Numerous teams and individual authors made use of this situation. A collective monograph titled The Dynamics of Contemporary Slovak Lexicon [Dynamika slovnej zásoby súčasnej slovenčiny, 4] later became the most significant piece of academic work in this area. In addition to bringing numerous theoretical contributions and research innovations, its authors (Horecký, Buzássyová, Bosák et al.) also built on those methods and outputs of Slovak linguistics that had been focusing on empirical research. During the preparatory phase of the book's production, the authors created a separate card catalog with words and phrases including context. This card catalog consisted of manual excerpts of documents not captured in the dictionaries of Slovak that were available at the time. Although such an extensive preparation of materials was not common in the 1980s, it yielded 
valuable results by providing a unique description of the dynamics of Slovak lexicon in the 1970s and the first half of the 1980s.

Another contribution that can be attributed to this book is its partial departure from a purely systemic approach to linguistic phenomena and its adoption of a communication-focused approach. The communication needs that influence the borrowing of new words and the openness of Slovak towards words from other languages, especially internationalisms of Graeco-Latin origin, are two ideas that also appear in other places. Klára Buzássyová, one of the co-authors of [4], mentions them in her own works (e.g. [5]) and a collective monograph titled The Recent History of Slavic Languages. Slovak (Najnowsze dzieje języków słowiańskich, [6, pp. 40-43]). Just like the former monograph, the latter is also based on a large number of specific excerpts collected from imaginative, professional, and journalistic texts. A large portion of these were manually excerpted by individuals, with written texts being the primary source and various types spoken communication a less frequent one. Research from this period usually quantified the occurrence of linguistic units using the words "frequent", "less frequent", "rare", "productive", and "unproductive" without precise quantification. Although these examples were collected and analyzed manually, the results of this research still prove to be valid in the present day, when they are verified in large corpora using modern corpus-based methods. Another feature of manual research is that these texts often include a large number of marginal, very infrequent phenomena, which are more likely to be recorded in manual excerption due to their various peculiarities.

In recent decades, there have been significant developments in the potential for using corpus-based textual and linguistic resources, i.e. working with linguistic materials by collecting written and spoken texts and making them available for research in large electronic databases. Corpus-based quantitative analysis of texts and methods of analyzing linguistic changes have been introduced in detail by researchers such as Václav Cvrček [7] and Michal Křen [8]. Cvrček points out that corpus linguistics has, among other things, made linguistic research place emphasis on empiricism and quantitative methods, while focusing more on parole [7, p. 11]. This statement can be specified using the ideas mentioned above: extensive and well-structured corpus resources have enabled the use of corpus-linguistic research methods to significantly expand the possibilities of empirical language research, especially the research of parole, thus meeting the often emphasized needs of many linguists (both Slovak and international) who had previously been aware of the limitations in their research that had caused by a lack of research materials. The current situation in regard to research material is different: "A well-known advantage of corpus linguistics, which might be taken for granted nowadays, is having a sufficient (sometimes even excessive) amount of empirical data and being able to easily quantify all quantifiable phenomena" $[8$, p. 11]. However, this advantage also has its pitfalls. 
When comparing the potential for analyzing research materials before the existence of corpus resources and now, the present approach has numerous indisputable advantages. Corpora, corpus linguistics, and quantitative linguistics now play an irreplaceable role in the analysis of language, especially in the area of synchronic dynamics. Yet despite all the improvements and development it has undergone, corpusbased research still encounters limits and difficulties (cf. e.g. [9]). One problem stems from the difficulty of appropriately managing the amount of available corpus material (also from a time perspective). For instance, if a classical linguist initially tries to do corpus-based research, it often becomes corpus-driven because the linguistic material available in real-world texts starts providing new perspectives and provoking new questions. However, the large number of available documents may cause the analysis only to focus on a few frequently occurring phenomena, which is why less frequent (albeit from a linguistic perspective interesting) linguistic units usually do not receive any attention. It appears that the classical linguists who previously used manual excerption were able to capture these infrequent phenomena well.

This paper aims to combine a corpus-linguistic and quantitative approach with a more detailed manual analysis of the acquired linguistic material. The analysis should reveal dynamics and competing functioning of word-formation types with either an international or domestic formative element, i. e., words ending in -ita/-ost'. The paper concludes with a comparison of results from this partial analysis and the findings regarding the dynamics of words ending in -izmus/-stvo (cf. [10]). We presume that functioning of these words in contemporary written communication is different, although they represent similar groups of abstract words.

\section{MATERIAL RESOURCES FOR THE ANALYSIS OF WORDS ENDING IN -ita/-ost'}

This research is based on the resources provided by the Slovak National Corpus of the L'udovit Štúr Institute of Linguistics (SNC) listed in Table 1.

\begin{tabular}{|l|l|l|l|}
\hline \multicolumn{1}{|c|}{ Corpus name } & \multicolumn{1}{|c|}{ Corpus size } & \multicolumn{1}{c|}{ Corpus composition } & Texts created in \\
\hline r1955az1989-5.0 & 83.6 million tokens; & $5.11 \%$ journalistic, & $1955-1989$ \\
& 66.8 million words & $75.73 \%$ imaginative, & \\
& & $13.82 \%$ professional, & \\
& & $5.34 \%$ other texts & \\
\hline prim-8.0-public- & 1.4 billion tokens; & $73.75 \%$ journalistic, & $1955-2017 ;$ \\
sane & 1.1 billion words & $16.33 \%$ imaginative, & mainly texts \\
& & $8.91 \%$ professional, & written after \\
& & $1.01 \%$ other texts & 2000 \\
\hline web-4.0 & 3 billion tokens; & - & $?-2017$ \\
& 2.4 billion words & & \\
\hline
\end{tabular}

Tab. 1. The SNC's corpus resources used for analysis 
The SNC's resources were searched using the NoSketch Engine (https: // wWw.sketchengine.co.uk) and the [lemma=".*xxx"] CQL command, with the "xxx" string replaced with specific word endings, i.e. ita, ost'. The resulting concordances were then used to create frequency lists of lemmas. In addition to the desired abstract words with the analyzed formative elements, this formal search method also returned all other words with the same ending. The primary focus in each group was to compare the 20 most frequently occurring lemmas and, potentially, to compare the specific characteristics of additional expressions or the whole microsystem of the 1,000 most frequently occurring lemmas.

\section{THEORETICAL BASIS FOR THE ANALYSIS OF WORDS ENDING IN -ita/-ost'}

In the context of Slovak linguistics, the dynamic processes in abstract vocabulary have been systematically studied by Klára Buzássyová. She has focused on them in several partial studies: a detailed analysis of the competing wordformation types with the formative elements -ita/-ost' [11], which is also heavily utilized in this paper; an analysis of their negative forms [12]; and a summary of abstract vocabulary, especially the competing formative elements -ita/-ost', which was presented in the collective monograph [4]. As stated by Buzássyová, "words with this structure have the same characteristics as abstract words in general: they are part of intellectual vocabulary, often formal or professional from a stylistic perspective" and they typically "a) form variants (linguistic units that are stylistically and semantically equivalent); b) find use as means of stylistic differentiation, i.e. as stylistic synonyms; c) form units that are partially differentiated, both semantically and from the perspective of communication areas (e.g. terminology, journalistic vocabulary, common vocabulary)" [11, pp. 142-143]. These findings will be verified by analyzing corpus materials with both older and newer written texts of traditional formats and materials from the web corpus, where a significant portion of texts combine features of written and spoken forms and they mainly use common vocabulary (cf. Table 1).

\section{WORDS ENDING IN -ita}

The list of words ending in -ita, which was composed using search of words forms, includes abstract nouns as well words denoting various entities (univerzita 'university', lokalita 'locality', maturita 'school-leaving examination'), proper nouns (Judita, Margita) or an acronym (SITA). Abstract vocabulary is not separately labeled in the corpus annotation, so automatic filters could only be used to remove proper nouns and non-feminine nouns (e.g. bandita 'bandit', masculine noun). 


\begin{tabular}{|c|l|l|l|}
\hline \multicolumn{1}{|c|}{$\boldsymbol{r 1 9 5 5 a z 1 9 8 9 - 5 . 0}$} & \multicolumn{1}{c|}{ prim-8.0-public-sane } & \multicolumn{1}{c|}{ web-4.0 } \\
\hline 1. & kvalita 'quality' & aktivita 'activity' & kvalita 'quality' \\
\hline 2. & univerzita 'university' & kvalita 'quality' & aktivita 'activity' \\
\hline 3. & aktivita 'activity' & univerzita 'university' & univerzita 'university' \\
\hline 4. & realita 'reality' & realita 'reality' & lokalita 'locality' \\
\hline 5. & kapacita 'capacity' & kapacita 'capacity' & realita 'reality' \\
\hline 6. & autorita 'authority' & lokalita 'locality' & kapacita 'capacity' \\
\hline 7. & lokalita 'locality' & SITA & komunita 'community' \\
\hline 8. & Judita & priorita 'priority' & priorita 'priority' \\
\hline 9. & intenzita 'intensity' & komunita 'community' & stabilita 'stability' \\
\hline 10. & Margita & stabilita 'stability' & intenzita 'intensity' \\
\hline 11. & kontinuita 'continuity' & identita 'identity' & identita 'identity' \\
\hline 12. & bandita 'bandit' & autorita 'authority' & imunita 'immunity' \\
\hline 13. & nervozita 'nervosity' & elita 'elite' & autorita 'authority' \\
\hline 14. & Univerzita 'University' & charita 'charity' & sppecialita 'speciality' \\
\hline 15. & relativita 'relativity' & solidarita 'solidarity' & elita 'elite' \\
\hline 16. & popularita 'popularity' & popularita 'popularity' & efektivita 'effectivity' \\
\hline 17. & maturita 'school-leaving & intenzita 'intensity' & popularita 'popularity' \\
\hline 18. & individualita 'individuality' & komodita 'commodity' & kreativita 'creativity' \\
\hline 19. & formalita 'formality' & imunita 'immunity' & solidarita 'solidarity' \\
\hline 20. & produktivita 'productivity' & $\begin{array}{l}\text { maturita 'school-leaving } \\
\text { examination' }\end{array}$ & produktivita 'productivity' \\
\hline
\end{tabular}

Tab. 2. The 20 most frequently occurring words ending in -ita that appear in the SNC's corpora

A look at the list of the most frequently occurring words ending in -ita shows that the three top-ranking words are the same in all three corpora (albeit in different order). A total of 9 words appear in each of the three corpora, which indicates that their high frequency of use has been stable throughout different periods and styles. Two of the most frequently occurring words are abstract nouns that have form ending in -ost' (aktivita, kvalita) whose use is acceptable. Virtually all abstract nouns ending in the international formative element -ita can have alternative forms with the domestic formative element -ost', although in many cases this possibility is merely hypothetical and the domestic forms are used less frequently in practice, if they are used at all. Buzássyová [11] points out that these systemically possible variants of derived words almost exclusively used in the international form were recorded by authors of dictionaries (back then, these were the authors of Dictionary of the Slovak Language 'Slovník slovenského jazyka', 1959-1968), even though the research materials (the card catalog) did not provide sufficient evidence for their support.

What follows is a list of words that Buzássyová includes in this group along with their actual occurrence in the general prim-8.0-public-sane corpus. Since this 
comparison lists the occurrence of two words in the same corpus, the quantitative data is presented in the form of absolute frequency:

$\begin{array}{lrlrl}\text { totalita } & 9,888 & \text { totalitnost' } & 6 & \text { 'totality' } \\ \text { nervozita } & 17,799 & \text { nervóznost' } & 6 & \text { 'nervosity' } \\ \text { brutalita } & 3,179 & \text { brutálnost' } & 155 & \text { 'brutality' } \\ \text { invalidita } & 2,453 & \text { invalidnost' } & 0 & \text { 'invalidity' } \\ \text { sexualita } & 7,167 & \text { sexuálnost' } & 96 & \text { 'sexuality' } \\ \text { periodicita } & 1,979 & \text { periodickost' } & 18 & \text { 'periodicity' }\end{array}$

The data indicates that even in contemporary texts these hybridisms formed by derivation (foreign root + domestic formative element) only appear rarely, if they appear at all. Buzássyová confirms this idea by saying that the "forms with the formative element -ita are virtually the only versions that appear, they are neutral from a stylistic perspective, and their formal/professional character is not perceived [by users]" [11, p. 144]. However, a similar situation arises when studying pairs of words with international bases and international/domestic formative elements. Buzássyová [Ibid., p. 145] labels these "expressive variants, i.e. linguistic units that are neutral and equivalent from a semantic and stylistic perspective". In this group of words in the prim-8.0-public-sane corpus, those with an international formative element are strongly predominant. However, there are two pairs (absurdita absurdnost' 'absurdity', objektivita - objektivnost' 'objectivity') whose occurrences are not so diametrically different:

$\begin{array}{lrlrl}\text { agresivita } & 9,926 & \text { agresívnost' } & 329 & \text { 'aggressivity' } \\ \text { absurdita } & 3,477 & \text { absurdnost' } & 2,178 & \text { 'absurdity' } \\ \text { aktivita } & 216,776 & \text { aktívnost' } & 520 & \text { 'activity' } \\ \text { genialita } & 1,925 & \text { geniálnost' } & 152 & \text { 'geniality' } \\ \text { kolegialita } & 619 & \text { kolegiálnost' } & 89 & \text { 'collegiality' } \\ \text { objektivita } & 3,491 & \text { objektínnost' } & 2,493 & \text { 'objectivity' } \\ \text { popularita } & 21,561 & \text { populárnost' } & 170 & \text { 'popularity' } \\ \text { stabilita } & 36,704 & \text { stabilnost' } & 127 & \text { 'stability' } \\ \text { nestabilita } & 5,046 & \text { nestabilnost' } & 117 & \text { 'instability' }\end{array}$

From the perspective of their occurrence in contemporary texts, next group of words can be labeled as the most heterogeneous one. According to Buzássyová, this group is the "core of correlation between words belonging to the -ita/-ost' wordformation types" and also the "most dynamic component of this lexico-semantic and word-formation microsystem, which most clearly documents the dynamics in this part of the vocabulary" [Ibid., p. 146]. These are pairs where each word has differentiated itself as a stylistic synonym. Buzássyová states that forms with the formative element -ita have a (more) formal character, while forms ending in the domestic suffix -ost' are neutral and less formal. Although the frequency of these 
words is usually low for both words in the pair (perhaps equally formal in situations like these), this group also includes pairs where the versions ending in the domestic suffix -ost' prevail, which would indicate that they are more neutral and common, e.g. slovenskost', plastickost', poetickost':

$\begin{array}{lrlrl}\text { uniformita } & 941 & \text { uniformnost' } & 43 & \text { 'uniformity' } \\ \text { autenticita } & 2,765 & \text { autentickost' } & 2,502 & \text { 'authenticity' } \\ \text { labilita } & 514 & \text { labilnost' } & 102 & \text { 'lability' } \\ \text { atraktivita } & 4,614 & \text { atraktívnost' } & 2,543 & \text { 'attractiveness' } \\ \text { akceptabilita } & 1 & \begin{array}{l}\text { akceptabilnost' } \\ \text { akceptovatelnost' }\end{array} & 314 & \text { 'acceptability' } \\ & & \text { 'acceptableness' } \\ \text { aplikabilita } & 4 & \begin{array}{l}\text { aplikabilnost' } \\ \text { aplikovatel'nost' }\end{array} & 199 & \text { 'applicability' } \\ \text { direktivita } & 3 & \text { direktívnost' } & 33 & \text { 'applicableness' } \\ \text { historicita } & 223 & \text { historickost' } & 321 & \text { 'historitititiveness' } \\ \text { slovacita } & 41 & \text { slovenskost' } & 770 & \text { 'Slovakness' } \\ \text { plasticita } & 272 & \text { plastickost' } & 328 & \text { 'plasticity' } \\ \text { poeticita } & 0 & \text { poetickost' } & 360 & \text { 'poeticness' } \\ \text { potencialita } & 117 & \text { potenciálnost' } & 24 & \text { 'potentiality' } \\ \text { sugestivita } & 64 & \text { sugestívnost' } & 321 & \text { 'suggestiveness' } \\ \text { simultaneita } & 5 & \text { simultánnost' } & 150 & \text { 'simultaneousness' }\end{array}$

Words ending in the analyzed formative elements -ita/-ost' (ale aj -izmus/-stvo, cf. [10]) have a strong tendency towards prefixation and compounding (cf. [5, pp. 120-122]). The group of words ending in -ita have shown to have 49 different prefixes and prefixoids among the 1,000 most frequent lemmas in the prim-8.0public-sane corpus, including compound words with the same format as seropozitivita 'seropositivity'. These prefixes and prefixoids include: $a$-, ab-, agro-, auto-, bi-, bio-, cyto-, de-, dis-, elektro-, ex-, extra-, foto-, gastro-, hepato-, hetero-, homo-, hyper-, hypo-, i-, ichno-, in-, inter-, kardio-, ko-, kon-, kyber-, meteo-, multi-, ne-, nefro-, neuro-, non-, perme-, poly-, post-, pro-, pseudo-, rádio-, re-, retro-, séro-, sub-, super-, štvor-, termo-, trans-, tri-, uni- (e.g. diskontinuita 'discontinuity', hyperaktivita 'hyperactivity', iracionalita 'irrationality', multikulturalita 'multiculturality', rádioaktivita 'radioactivity', superkvalita 'superquality').

The most frequently occurring words are hybrid compound words with the domestic prefix ne- (16 derived forms; e.g. nestabilita 'instability', nekvalita 'poor quality'), which are interpreted as negative forms. Most of the other prefixes are international: inter- (9 derived forms), hyper- (6), multi- (4), a-, bi-, dis-, i-, in- (3 derived forms each). The most used word bases are -aktivita ( 9 derived forms), -sexualita (7), -toxicita (4). 


\section{WORDS ENDING IN -ost'}

The list of words ending in -ost' also includes forms that are not abstract names of qualities, which could be automatically filtered out by removing non-feminines and non-nouns (dost' 'quite' - adverb, host' 'guest' - masculine). Not a single word presented in Table 3 allows the creation of a form ending in -ita and the entire analyzed group of 1,000 most frequent lemmas ending in -ost' includes very few words that do (e.g. efektivnost' - efektivita 'effectivity', aktuálnost' - aktualita 'actuality', atraktívnost' - atraktivita 'attractivity").

\begin{tabular}{|r|l|l|l|}
\hline & \multicolumn{1}{|c|}{ r1955az1 1989-5.0 } & \multicolumn{1}{|c|}{ prim-8.0-public-sane } & \multicolumn{1}{c|}{ web-4.0 } \\
\hline 1. & dost' 'enough' & spoločnost' 'company' & spoločnost' 'company' \\
\hline 2. & spoločnost' 'company' & možnost' 'possibility' & možnost' 'possibility' \\
\hline 3. & činnost' 'activity' & host' 'guest' & činnost' 'activity' \\
\hline 4. & skutočnost' 'reality' & činnost' 'activity' & skúsenost' 'experience' \\
\hline 5. & možnost' 'possibility' & dost' 'enough' & dost' 'enough' \\
\hline 6. & radost' 'joy' & súčasnost' 'the present' & súčasnost' 'the present' \\
\hline 7. & pozornost' 'attention' & príležitost' 'opportunity' & skutočnost' 'reality' \\
\hline 8. & udalost' 'event' & skutočnost' 'reality' & príležitost' 'opportunity' \\
\hline 9. & miestnost' 'room' & skúsenost' 'experience' & schopnost' 'ability' \\
\hline 10. & host' 'guest' & minulost' 'the past' & povinnost' 'duty' \\
\hline 11. & príležitost' 'opportunity' & budúcnost' 'the future' & vel'kost' 'size' \\
\hline 12. & skúsenost' 'experience' & radost' 'joy' & host' 'guest' \\
\hline 13. & minulost' 'the past' & súvislost' 'connection' & starostlivost' 'care' \\
\hline 14. & budúcnost' 'the future' & verejnost' 'the public' & budúcnost' 'the future' \\
\hline 15. & súvislost' 'connection' & povinnost' 'duty' & radost' 'joy' \\
\hline 16. & starost' 'worry' & udalost' 'event' & minulost' 'the past' \\
\hline 17. & povinnost' 'duty' & pozornost' 'attention' & verejnost 'the public' \\
\hline 18. & vlastnost' 'characteristic' & žiadost' 'request' & udalost' 'event' \\
\hline 19. & schopnost' 'ability' & schopnost' 'ability' & vlastnost' 'characteristic' \\
\hline 20. & prítomnost' 'presence' & osobnost' 'personality' & miestnost' 'room' \\
\hline
\end{tabular}

Tab. 3. The 20 most frequently occurring words ending in -ost' that appear in the SNC's corpora

The cumulative occurrences for the entire group of words ending in -ost' in the prim-8.0-public-sane corpus are 5,5 times bigger than for the group of words ending in -ita, even though the second one relatively frequently includes proper names: .*ost' $10,580,133-. *$ ita $1,870,719$. This context makes the results from the previous section, which showed that in cases of competing pairs, internationalisms with the formative element -ita were predominant, even more remarkable. In comparison with the most frequent words ending in -ita (tens of thousands of occurrences), there are generally more words ending in -ost' and the frequency of the most frequent individual words is much higher (hundreds of thousands of occurrences). 
Compared to the other groups of abstract names that have been analyzed so far (words ending in -ita, -izmus, -stvo), words ending in -ost' have a specific tendency towards derivational prefixation and compounding. The prefixes include 10 formative elements (bez-, in-, nad-, ne-, pre-, pred-, proti-, roz-, $z$-, za-), which are almost exclusively domestic (with the exception of $i n$ ) and with a strong prevalence of the prefix ne- (129 derived forms). However, a significant number of words formed using prefixes have been lexicalized and their origin via prefixation is no longer clearly felt (e.g. zaslepenost' 'blindness', prejazdnost' 'traffic flow', predvídatel'nost' 'predictability', rozpracovanost' 'unfinished character').

Compound words make up a much larger part of this group. They have 53 different initial elements whose semantic content usually refers to measure and quality (e.g. jedno- 'one-', vše- 'all-', každo- 'every-', dobro- 'well-', l'ahko- 'easy-'). The most common final elements of compound words are -schopnost' (7 compound words), -hodnost' (5), and -mysel'nost' (5), e.g.: ciel'avedomost' 'single-mindedness', l'ahkomysel'nost' 'carelessness', mnohotvárnost' 'multiformity', samolúbost' 'selfsatisfaction'.

\section{CONCLUSION}

The synchronic dynamics of language, the topic of internationalization as a general trend, and the relationship between domestic and international words have been studied by several authors. In Slovakia, most of this work was done in the 1980s. This analysis of words ending in -ita/-ost' has primarily focused on two aspects of these topics that have not been exhaustively studied: a study of the extensive materials currently offered by corpus databases and especially an analysis of the way abstract vocabulary functions within the whole lexicon and within the microsystems of words ending in -ita/-ost'. Some of the previous observations and partial conclusions have been confirmed or specified using frequency data, while others will require further detailed analysis.

The considerable tendency of word formation using prefixes, semiprefixes, and compounding (even by combining domestic and international elements) that has been identified in the group of words ending in -izmus/-stvo (cf. [10]) can also be seen in the group of words ending in -ita. Here, prefixation typically uses foreign prefixes and semiprefixes. The group of words ending in -ost includes an unusually rich and diverse collection of compound words. Unlike the group of words ending in -izmus and partially the group of words ending in -stvo, the group of words formed using -ita/-ost does not include any productive type of word formation using first or last names. Furthermore, no active type of word formation using pejoratives and ironic words has been identified in this group. From the perspective of frequency, overall the group of words ending in -ost is much more utilized than the group of words ending in -ita, but an analysis of competing forms with international and 
domestic formative elements shows that the particular words ending in -ita is more utilized than the same word bases with suffix -ost', from the perspective of both function and frequency. This analysis of contemporary texts indicates that the competition between international and domestic formative elements is often very strong and the processes of intellectualization and internationalization in contemporary Slovak do not occur the same way in all lexical microsystems. On the contrary, language users select an appropriate form based on their own communication needs.

\section{References}

[1] Barnet, V. (1981). Synchronní dynamika spisovného jazyka. Jazykovedný časopis, 32(2), pages 123-130.

[2] Jedlička, A. (1981). Vývojové procesy a synchronní dynamika jazyka v konfrontačním osvětlení. Jazykovedný časopis, 32(2), pages 107-116.

[3] Horecký, J. (1988). Dynamickost' a dynamika v jazyku. In Studia Academica Slovaca. 17. pages 189-199, Bratislava, Alfa.

[4] Horecký, J., Buzássyová, K., Bosák, J. et al. (1989). Dynamika slovnej zásoby súčasnej slovenčiny. Bratislava, Veda.

[5] Buzássyová, K. (2010). Vzt’ah internacionálnych a domácich slov v premenách času. Jazykovedný časopis, 61(2), pages 113-130.

[6] Najnowsze dzieje języków słowiańskich. Slovenský jazyk. (1998). Opole, Uniwersytet Opolski - Instytut Filologii Polskiej.

[7] Cvrček, V. (2013). Kvantitativní analýza kontextu. Praha, Ústav Českého národního korpusu - Nakladatelství Lidové noviny.

[8] Křen, M. (2013). Odraz jazykových změn v synchronních korpusech. Praha, Ústav Českého národního korpusu - Nakladatelství Lidové noviny.

[9] Šimková, M., Gajdošová, K., Kmet’ová, B., and Debnár, M. (2017). Slovenský národný korpus. Texty, anotácie, vyhl’adávania. Bratislava, Jazykovedný ústav L'. Štúra SAV - Vydavatel'stvo Mikula.

[10] Šimková, M. (2018). Synchrónna dynamika slov zakončených na -izmus/-stvo v textoch Slovenského národného korpusu. Jazykovedný časopis, 69(3), pages 560-571.

[11] Buzássyová, K. (1986a). Konkurencia slovotvorných typov s formantmi -ita a -ost'. Slovenská reč, 51(3), pages 142-152.

[12] Buzássyová, K. (1986b). Novšie názvy negatívnych vlastností a stavov. Kultúra slova, 20(10), pages 335-340.

[13] Slovenský národný korpus. Verzia prim-8.0-public-sane. Bratislava: Jazykovedný ústav L. Štúra SAV 2018. Accessible at: https: / / korpus.juls. savba.sk.

[14] Slovenský národný korpus. Korpus r1955az1989-5.0. Bratislava: Jazykovedný ústav L. Štúra SAV 2018. Accessible at: https: / / korpus. juls.savba.sk.

[15] Slovenský národný korpus. Korpus web-4.0. Bratislava: Jazykovedný ústav L. Štúra SAV 2018. Accessible at: https: / / korpus.juls.savba.sk.

[16] https://www.sketchengine.co.uk. 